\title{
A comparison of bird communities in natural and disturbed non-wetland open habitats in the Cerrado's central region, Brazil.
}

DÁRIUS P. TUBELIS and ROBERTO B. CAVALCANTI

\begin{abstract}
Summary
In the Cerrado of Brazil, the largest Neotropical savanna region, open habitats are suffering an intense process of conversion to pasture and agricultural land. This study evaluated the responses of birds to the thinning of tree and shrub cover in plots of cerrado sensu stricto, the dominant habitat in the region, and examined whether disturbed plots supported bird communities of open natural habitats with similar structure. Birds were censused by point counts in five disturbed sites and in seven preserved patches, with a total of 304 samples of 20 minutes in 68 points. Cleared plots were not suitable for species strongly dependent on trees and shrubs, such as frugivores and most insectivores. Their abundance was associated with the complexity of vegetation structure in these plots. Shrubby pastures held about $120 \%$ more species than the traditional cleared ones. Bird communities of pastures showed large differences in relation to those of grasslands with similar structure. Communities of pastures were dominated by a seedeater, the Blue-black Grassquit Volatinia jacarina, and most species were habitat generalist or oportunistic predators, such as raptors and insectivores. Obligate grassland species, like the Grass Wren Cistothorus platensis, Cock-tailed Tyrant Alectrurus tricolor and Black-masked Finch Coryphaspiza melanotis, as well as other abundant species in grasslands, such as Sharp-tailed Grass-tyrant Culicivora caudacuta and Capped Seedeater Sporophila bouvreuil do not adapt to pastures. Grassland grasses probably do not recover spontaneously in abandoned pastures and in other agricultural lands. Thus, conservation of grassland birds will strongly depend on a urgent programme of identification and protection of large areas of Cerrado dominated by campo limpo and campo sujo. These species would also benefit from the maintenance of a band of grassland along gallery forests.
\end{abstract}

\section{Introduction}

The Cerrado, the second largest South American biome, is a savanna formation that dominates the central region of Brazil (Sarmiento 1983, Ab' Saber 1977). It also occurs as connected or disjunct patches in the adjacent provinces of Chaco, Caatinga, Atlantic Forest and Amazonia (Eiten 1993). In a large extension of its range, the Cerrado occurs as a naturally patchy environment, presenting habitats like those of cerrado sensu lato, mesophytic and gallery forests, marshes and rock campos (Eiten 1993). The cerrado sensu lato, that covered originally $85 \%$ of the Cerrado region, comprise a gradient from pure grassland to forest (the cerradão). 
Four open habitats are often recognized: campo limpo, campo sujo, campo cerrado and cerrado sensu stricto (Eiten 1993).

This diversified landscape harbours about 840 bird species, of which $9.3 \%$ are migratory and 3.8\% endemics (Silva 1995). Of the 759 Cerrado resident species, $208(27.4 \%)$ are typical of open habitats (cerrado sensu lato, marshes and rocky campos), and another $158(20.8 \%)$ use both open and forested habitats (Silva 1995). Besides containing almost half of the Cerrado bird richness, open habitats support a considerable number of rare and endemic species (Stotz et al. 1996).

Approximately $80 \%$ of the original cover of the Cerrado has been converted to pasture, crops and other agricultural practices (Meyers et al., 2000). Large-scale mechanized agriculture is considered to be the main factor in putting at risk about $75 \%$ of the Cerrado endemic bird species (Stotz et al. 1996). The Cerrado non-wetland open habitats often occur in places with flat topographies, growing over soils with good drainage. Further, they are easily cleared. These characteristics make open habitats of cerrado sensu lato excellent places for conversion to large-scale agribusiness operations.

Despite the accelerated habitat loss, studies examining the effects of alteration of cerrado sensu stricto on birds have not been conducted. In addition to being the dominant habitat in Cerrado, cerrado sensu stricto is extremely important for birds. It supports both great bird abundance and species richness (Negret 1983, Lins 1994, Stotz et al. 1996), receives gallery forest birds seasonally (Cavalcanti 1992) and contributes to the structure of forest communities (Lins 1994).

Agriculture and pasturelands cause variable levels of disturbance in distinct strata of habitats, generally leading to a simplification of the vegetation structure, with consequent impact on bird communities (Wiens and Rotenberry 1985, Johns 1991, Greenberg et al. 1995). In the Cerrado, cerrado sensu stricto stands converted to pasture tend to suffer great structural simplification, resulting in a structure similar to that of more open habitats, like grasslands. An understanding of the disturbance impact and of the role of these converted habitats in maintaining a portion of the original community is essential for the conservation of species in intensively exploited regions.

This study examines the response of bird species to the reduction in the tree and shrub cover (anthropogenic structural disturbance) and grassland layer replacement in plots of cerrado sensu stricto, and examines whether the altered stands support the bird communities of more open natural habitats of Cerrado with similar structure.

\section{Study area}

The study was conducted in the Federal District of Brazil, in the central region of Cerrado core area. The natural vegetation plots are located in the "Fazenda Água Limpa" of Universidade de Brasília ( $15^{\circ} 57^{\prime} \mathrm{S}, 47^{\circ} 55^{\prime} \mathrm{W}$ ) and at "Estação Ecológica do Jardim Botânico de Brasília" ( $15^{\circ} 55^{\prime} \mathrm{S}, 47^{\circ} 52^{\prime} \mathrm{W}$ ). These two areas, together with the IBGE reserve represent a 10,000 ha continuous landscape with preserved tracts of most Cerrado habitats. The disturbed areas were located adjacent to a cerrado sensu stricto patch of Jardim Botânico, separated only by a road.

The regional climate is Aw according to the Köppen climatic classification. The mean annual precipitation is approximately $1500 \mathrm{~mm}$, with $90 \%$ of this falling 
from October to April. The dry season occurs between May and September (Eiten 1993). Additional general information on the region can be found in Pinto (1993).

The cerrado sensu lato covered originally $85 \%$ of the Cerrado region and represents a gradient of non-wetland physiognomic forms. In this gradient, the density of trees and shrubs is dependent on substrate aspects and periodic fires (Eiten 1993). We adopted Eiten's (1993) division of cerrado sensu lato, which includes the cerradão (a forest) and four open habitats with decreasing density of shrub layer: cerrado sensu stricto, campo cerrado, campo sujo and campo limpo. Biomass of the gramineous layer is greater in grasslands, but is continuous in all open habitats (Castro and Kauffman 1998). These habitats are briefly described below.

The cerrado sensu stricto (SS) is the dominant phytophysiognomy in Cerrado with trees $3 \mathrm{~m}$ or more high which provide a cover of 10 to $30 \%$, not forming a continuous canopy. In a few cases, trees might promote a cover of $60 \%$ (Eiten 1993). The campo cerrado (CC) is dominated by the shrub and herbaceous layer, with a few sparse trees often ranging from 2 to $5 \mathrm{~m}$ height, and tree cover in the 2 to $15 \%$ range (Ribeiro et al. 1983 , Sarmiento 1983 ).

The campo sujo (CS) has an almost continuous herbaceous layer, with tree and shrubs sparsely distributed with less than $2 \%$ cover, being mostly less developed individuals of cerrado sensu stricto tree species (Ribeiro et al. 1983, Sarmiento 1983). The campo limpo (CL) has only the herbaceous layer, with occasional shrubs that do not grow higher than the surrounding grasses (Sarmiento 1983, Eiten 1993).

We selected 12 study sites (Table 1), including seven preserved patches of open habitats of cerrado sensu lato and five disturbed sites of cerrado sensu stricto with distinct levels of shrub and tree cover. We selected disturbed patches presenting a vegetational structure similar to those of the more open habitats of cerrado sensu lato. Thus, the disturbed habitats are similar to campo limpo, campo sujo and campo cerrado and are briefly described below.

Partially cleared cerrado (PCC) Disturbed cerrado sensu stricto now presenting a structure similar to that of campo cerrado. It has many short and tall shrubs, as well as some young trees. Its herbaceous stratum is dominated by the exotic grasses Brachiaria spp. and Melinis minutiflora.

Shrubby pastures (SP) Altered stands of cerrado sensu stricto, now similar to campo sujo. The herbaceous stratum has no native species and is dominated by Brachiaria spp. and Melinis minutiflora. It has few trees, many shrubs and a well developed herbaceous stratum.

Cleared pastures (CP) Disturbed stands of cerrado sensu stricto, being structurally similar to campo limpo. There are no trees, only some sparse shrubs of the same height as the herbs. The exotic species Brachiaria sp and Melinis minutiflora dominate the herbaceous stratum.

\section{Methods}

Bird surveys

Bird counts were conducted from June 1995 to April 1996 by D.P.T. in 58 stations (points) distributed in the study sites. All sites were sampled within periods of 
40 days to avoid bias due to seasonality. The variable circular plot census method (Reynolds et al. 1980) was conducted between sunrise and o7h30, after which bird activity declined substantially. During 20 minute periods, the observer counted once each individual bird detected by vision or sound. Birds clearly outside the habitat in which the point was located were excluded. Counts started as soon as the observer arrived in the point. Two to three counts in distinct points were conducted each morning. The daily order of point sampling was changed to eliminate time-of-day morning bias. Counts were not conducted on rainy or windy mornings. For gregarious species such as the Curl-crested Jay Cyanocorax cristatellus and the Common Thornbird Phacellodomus rufifrons, we assumed groups heard but not seen had the mean group size for that species.

Points were located at least $200 \mathrm{~m}$ from the habitat edge to avoid recording birds present in adjacent habitats or birds that usually use edges or transitional vegetation. Sampling near roads was also avoided. Points were located at least $200 \mathrm{~m}$ from them to avoid disturbance by car noise and to avoid recording seedeaters like the Blue-black Grassquit Volatinia jacarina and the Stripe-tailed Yellowfinch Sicalis citrina which occur along roads to utilize colonizing exotic grasses. Points were spaced at least $200 \mathrm{~m}$ apart to increase the probability of sample independence. The number of points per site varied according to patch size and vegetation structure. In each habitat, all points were sampled the same number of times (Table 1 ).

Distinguishing the voices in the Elaenia genus was sometimes uncertain. Elaenia spp. probably contain records of the Small-billed Elaenia Elaenia parvirostris, White-crested Elaenia E. albiceps and unidentified voices of other Elaenia species which occur in the region.

\section{Habitat measures}

Vegetation sampling was conducted during March and April 1996 at 56 points where birds were counted (Table 1). We selected eight structural variables expected to affect the presence and abundance of bird species. At each point, three equidistant transects of $60 \mathrm{~m}$ each were positioned away from the point at which the observer counted birds. The cover of trees, shrubs and herbs was estimated by the line-intercept sampling method (Brower and Zar 1984). The densities of trees and shrubs were estimated by counting all individuals situated in a band $4 \mathrm{~m}$ wide along each transect. The height of the herbaceous stratum was measured each $5 \mathrm{~m}$ along the line. All shrubs and trees situated in the 240 $\mathrm{m}^{2}$ bands had their heights taken, except in the sites of cerrado sensu stricto, where only the trees and shrubs intercepted by the line were measured.

We classified plants into: herbs (plants with stem circumference less than 3 $\mathrm{cm}$, measured at $0.1 \mathrm{~m}$ height), trees (woody plants $3 \mathrm{~m}$ or higher, or with stem circumference larger than $10 \mathrm{~cm}$ at $1.5 \mathrm{~m}$ height) and shrubs (plants larger than herbs and smaller than trees). Distinction of individual shrubs and trees was based on the distance of their aerial parts. Two shrubs were considered distinct individuals when the distance between their foliage was greater than $50 \mathrm{~cm}$. For trees this distance was $2 \mathrm{~m}$. 
Table 1. Study sites, with their area, number of bird count points (NP), number of bird samplings per point $(\mathrm{S} / \mathrm{P})$, total number of samplings (TS) and number of points with vegetation sampling (NV)

\begin{tabular}{lccccc}
\hline Study sites & Area & NP & S/P & TS & NV \\
\hline Cerrado sensu stricto (SS1) & 180 & 12 & 3 & 36 & 6 \\
Cerrado sensu stricto (SS2) & 200 & 12 & 3 & 36 & 6 \\
Campo cerrado $\left(\mathrm{CC}_{1}\right)$ & 95 & 6 & 5 & 30 & 6 \\
Campo cerrado $\left(\mathrm{CC}_{2}\right)$ & 40 & 4 & 5 & 20 & 4 \\
Partially cleared cerrado (PCC1) & 55 & 6 & 5 & 30 & 6 \\
Campo sujo (CS1) & 35 & 4 & 6 & 24 & 4 \\
Campo sujo (CS2) & 40 & 4 & 6 & 24 & 4 \\
Shrubby pasture (SP1) & 35 & 4 & 5 & 20 & 4 \\
Shrubby pasture (SP2) & 50 & 4 & 5 & 20 & 4 \\
Campo limpo (CL1) & 55 & 4 & 8 & 32 & 4 \\
Cleared pasture (CP1) & 50 & 4 & 4 & 16 & 4 \\
Cleared pasture (CP2) & 30 & 4 & 4 & 16 & 4 \\
\hline
\end{tabular}

\section{Data analysis}

The abundances of bird species were standardized to provide a comparable scale, as the sampling effort varied among the study sites. In all analyses, we considered the relative abundance of species, which refers to the mean number of individuals recorded per 20 min counts at any point, study site or habitat.

A principal component analysis (PCA) on a covariance matrix was used to determine which bird species contributed most to variation among communities.

The Mantel test, a pair-wise statistical comparison of data matrices, was used to verify the existence of significant covariation between changes in bird communities and vegetation. The relative abundance of species and values for the eight structural variables were used in the bird and vegetation matrices, respectively. Mantel's asymptotic approximation was the method chosen and the algorithm was based on Douglas and Endler (1982). Sorensen was the distance measure used.

The Kruskal-Wallis one-way analysis of variance (ANOVA) was used to identify the existence of differences in the relative abundance of species between habitats. Each count of 20 minutes was considered as a sample.

\section{Results}

Vegetation

The differences between preserved and disturbed cerrado sensu stricto stands were observed both in tree cover and density, although values of all variables tended to diminish in the direction of cleared pastures (Figure 1).

Campo limpo and cleared pastures were very similar in both tree and shrub structural aspects. The differences were in the herb cover, which was about $30 \%$ greater in campo limpo (Figure 1). Campo sujo and shrubby pastures also were largely similar in structural variables, except for herb cover which was 30\% less in the pastures. Campo cerrado had differences in herb cover but also in tree cover and height, suggesting that trees in the partially cleared cerrado occur in similar densities but are younger than those in campo cerrado. 
In floristic composition, differences between preserved and disturbed habitats with similar structure were mainly due to the herb stratum, in which there was a complete substitution of native grasses by exotic ones. Differences in relation to other strata may be reduced because shrubs and trees in the more open habitats are less developed individuals of woody species found in cerrado sensu stricto stands (Ribeiro et al. 1983).

\section{Overall aspects of bird communities}

A total of 83 species and 7513 birds was recorded during 304 counts of 20 minutes. Considering all species, 50\% occurred in both preserved and disturbed habitats, $40.5 \%$ were restricted to preserved sites and $9.5 \%$ were found only in disturbed sites.

The first two principal components of the PCA explained together $83 \%$ of the variance among communities. PC 1 explained $61 \%$ of total variance, giving extremely high positive weight (0.92) for the Blue-black Grassquit Volatinia jacarina, and moderate and negative weights for common species in natural habitats, such as the Grass Wren Cistothorus platensis, in grasslands, and Turquoise-fronted Parrot Amazona aestiva and Lesser Elaenia Elaenia chiriquensis in cerrado sensu stricto (Table 2). Thus, this component separates communities of preserved stands of cerrado sensu lato from disturbed stands of cerrado sensu stricto, despite some (e.g. campo limpo and cleared pastures) having very similar vegetation structure (Figure 2).

The second component ( $\mathrm{PC}_{2}$ ) explained $22 \%$ of variance. Higher positive weights were given for common species in preserved cerrado sensu stricto, such as Cyanocorax cristatellus, Amazona aestiva, Elaenia chiriquensis and Phacellodomus rufifrons (Table 2). Higher negative weights were given to Cistothorus platensis, Wedge-tailed Grass-finch Emberizoides herbicola and Cock-tailed Tyrant Alectrurus tricolor, common in campo limpo and campo sujo. Thus, PC2 separates preserved habitats with denser wood layer from the grasslands (Figure 2) based basically on differences of abundance of these species.

The matrices of relative abundance of birds significantly covaried with changes in vegetation structure within the preserved gradient (Mantel test, $r=0.59, d f=$ infinite, $t=3.33, P<0.001)$. The covariation between the bird and vegetation matrices was also significant within the disturbed gradient (PL to PCC) (Mantel test, $r=0.62, d f=$ infinite, $t=2.06, P<0.04)$. This indicates that increasing modifications in the structure along the cerrado sensu lato gradient and along the regrowth of vegetation in pastures leads to increasing changes in bird community structure. On other hand, when the analysis included preserved and disturbed sites, the covariance was not significant (Mantel test, $r=0.40, d f=$ infinite, $t=3.31, P<0.01)$. Great differences in floristic composition of grasses between preserved and disturbed sites probably strongly contribute to this lower covariance.

Comparisons between preserved and disturbed habitats with similar structure

Cleared pasture (CP) and campo limpo (CL) These two habitats together held 25 species. Despite being similar in both species richness ( 16 in CP and 19 in CL) 

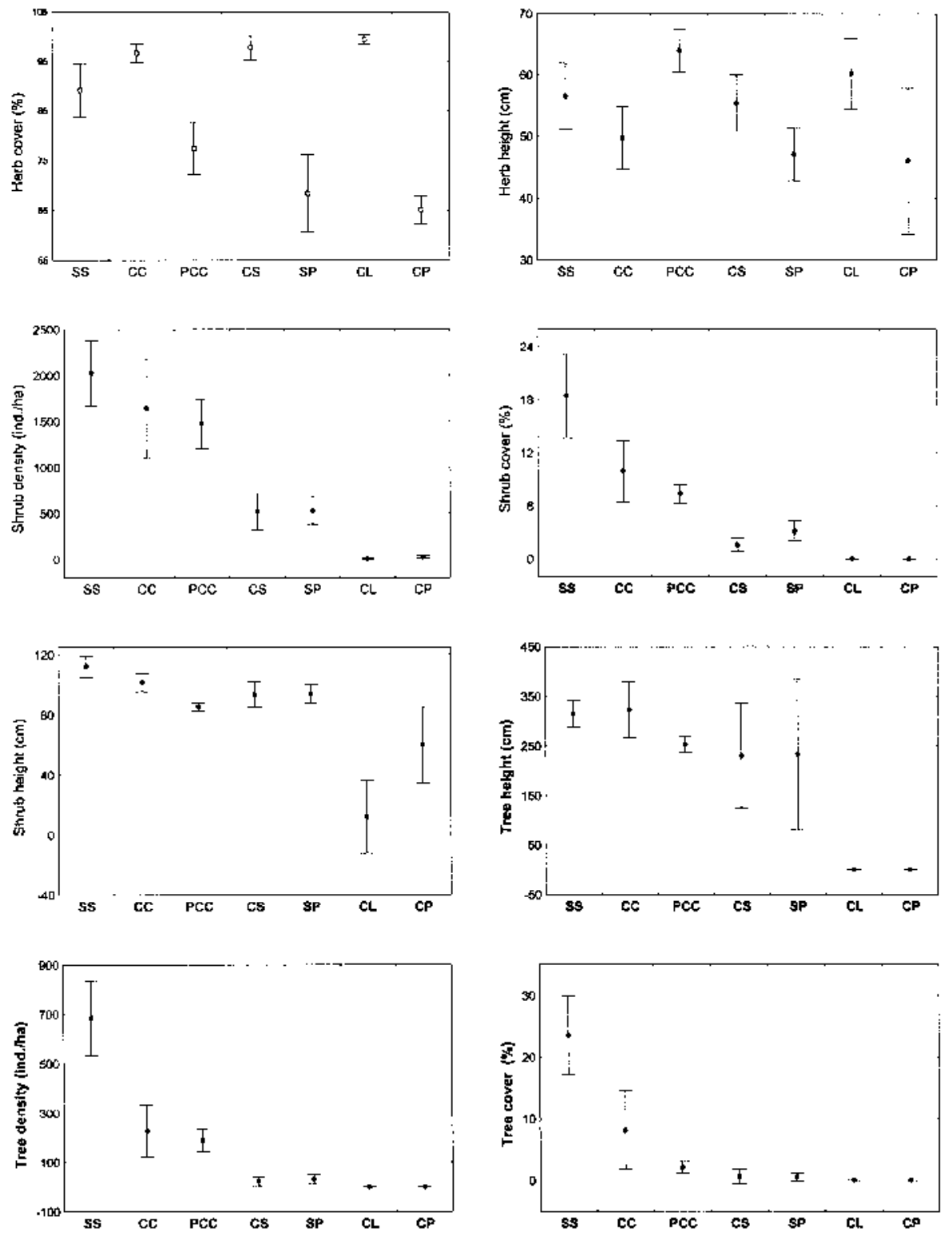

Figure 1. Mean values, with standard deviations, of the eight structural variables measured in 12 preserved and disturbed stands of non-wetland open habitats in Distrito Federal, Brazil. The preserved habitats are cerrado sensu stricto (SS), campo cerrado (CC), campo sujo (CS) and campo limpo (CL). The disturbed habitats are partially cleared cerrado (PCC), shrubby pastures (SP) and cleared pastures (CP). Numbers after each habitat class represent sites. 
Table 2. Component loadings of bird species on the two first components of the PCA. Only species with loadings larger that 0.1 on at least one component are listed

\begin{tabular}{lrr}
\hline Species & \multicolumn{1}{c}{ PC1 } & PC2 \\
\hline Small-billed Tinamou Crypturellus parvirostris & 0.00 & 0.11 \\
Turquoise-fronted Parrot Amazona aestiva & -0.16 & 0.35 \\
Common Thornbird Phacellodomus rufifrons & -0.08 & 0.23 \\
Collared Crescent-chest Melanopareia torquata & -0.01 & 0.10 \\
Cock-tailed Tyrant Alectrurus tricolor & -0.05 & -0.15 \\
Lesser Elaenia Elaenia chiriquensis & -0.12 & 0.24 \\
Suiriri Flycatcher Suiriri suiriri & -0.07 & 0.18 \\
Southern Beardless-tyrannulet Camptostoma obsoletum & -0.04 & 0.12 \\
Tawny-headed Swallow Alopochelidon fucata & 0.00 & -0.13 \\
Curl-crested Jay Cyanocorax cristatellus & -0.10 & 0.42 \\
Grass Wren Cistothorus platensis & -0.19 & -0.54 \\
House Wren Troglodytes aedon & -0.06 & 0.15 \\
White-banded Tanager Neothraupis fasciata & 0.00 & 0.22 \\
Blue-black Grassquit Volatinia jacarina & 0.92 & 0.05 \\
Plumbeous Seedeater Sporophila plumbea & 0.10 & 0.06 \\
Wedge-tailed Grass-finch Emberizoides herbicola & -0.09 & -0.22 \\
Eigen-value & 344.11 & 125.25 \\
\% of variance & 61.13 & 22.25 \\
\% accumulated & 61.13 & 83.38 \\
\hline
\end{tabular}

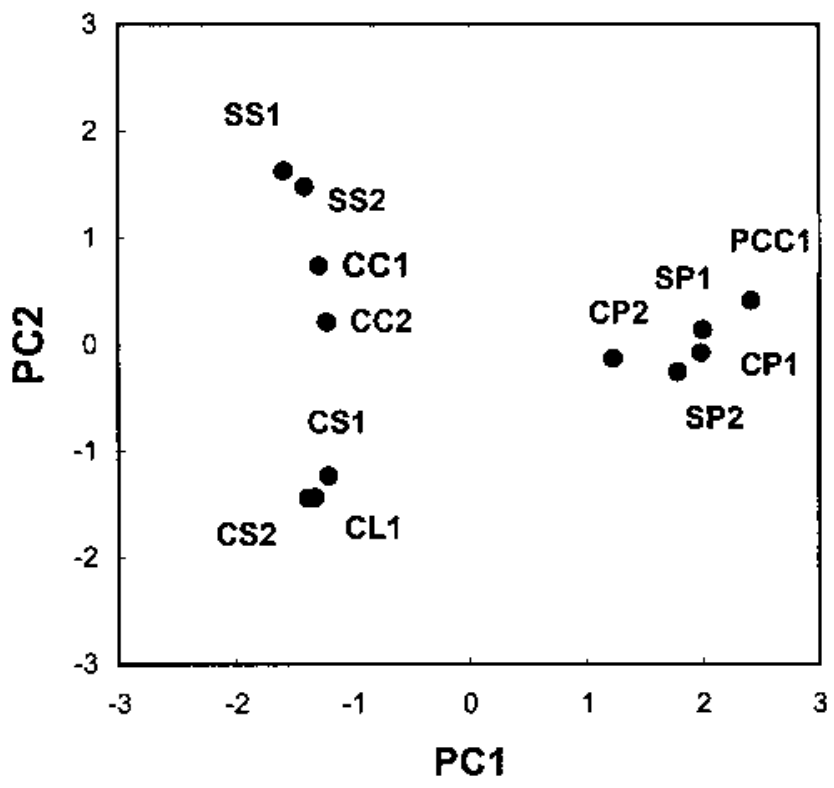

Figure 2. First two axes of a PCA ordination of preserved and disturbed cerrado sensu lato bird communities. CL, campo limpo; CS, campo sujo; CC, campo cerrado; SS, cerrado sensu stricto; PCC, partially cleared cerrado; $\mathrm{SP}$, shrubby pasture; $\mathrm{CP}$, cleared pasture. Numbers after each class represent sites. 
and proportion of habitat generalist species (62\% in CP and $63 \%$ in CL), their communities were very distinct. About $52 \%$ of bird species recorded in CL were not found in $\mathrm{CP}$, mostly obligate grassland birds. Among them are some of the most abundant species in CL, like Cistothorus platensis, Alectrurus tricolor, Culicivora caudacuta and Coryphaspiza melanotis.

Approximately $40 \%$ of the 25 species recorded in CL and CP occurred in both habitats, all species that use three or more habitats of the cerrado sensu lato. Emberizoides herbicola, the Red-winged Tinamou Rhynchotus rufescens and Tawnyheaded Swallow Alopochelidon fucata were significantly more abundant in campo limpo, while Small-billed Tinamou Crypturellus parvirostris, Grassland Sparrow Ammodramus humeralis and Stripe-tailed Yellow-finch Sicalis citrina were more abundant in the pastures. The other species included the Spotted Nothura Nothura maculosa, White-vented Violetear Colibri serrirostris and the Burrowing Owl Speotyto cunicularia, and had no significant difference in abundance between these two habitats.

Shrubby pasture (SP) and campo sujo (CS) A total of 51 species occurred in these habitats. Their communities were very dissimilar despite almost equal values of species richness (34 in SP and 38 in CS) and proportion of habitat generalist species ( $47 \%$ in SP and 55\% in CS). Approximately $45 \%$ of species found in campo sujo were not recorded in shrubby pastures and they can be separated into two groups. The first group contains 10 (77\%) obligate grassland species, such as Alectrurus tricolor and Coryphaspiza melanotis; the second harbours seven species that use campo sujo and one or two more habitats with denser wood layer, such as the White-rumped Tanager Cypsnagra hirundinacea and Amazona aestiva.

Approximately $41 \%$ of 51 species recorded in CS and SP occurred in both habitats and are distributed in three groups. The first group contains 16 species which occur in three or four habitats of the cerrado sensu lato gradient. Among them, Emberizoides herbicola, Culicivora caudacuta and Rhynchotus rufescens were significantly more abundant in campo sujo, while the Pale-breasted Spinetail Synnalaxis albescens, Sicalis citrina and Crypturellus parvirostris were more abundant in shrubby pastures. The other 10 species did not differ significantly between habitats. The second group contained three grassland species: Cistothorus platensis, which was recorded only once in shrubby pastures, the American Kestrel Falco sparverius and Brown-chested Martin Phaeprogne tapera, both insectivorous birds adapted to habitats influenced by human activity. The last group of common birds consisted of two species which were significantly more abundant in the shrubby pastures: Volatinia jacarina, the dominant species, and the Grey Monjita Xolmis cinerea, an insectivorous bird more frequent in campo sujo, considering the cerrado sensu lato gradient.

On the other hand, of the 13 species exclusive to shrubby pastures, most are insectivorous or raptors commonly recorded in habitats with a denser wood layer (campo cerrado and cerrado sensu stricto). 
Table 3. Total species richness and relative abundance (individuals per sample) of birds recorded in cerrado sensu stricto plots and in disturbed habitats

\begin{tabular}{|c|c|c|c|c|}
\hline Aspect of communities & $\begin{array}{l}\text { Preserved } \\
\text { cerrado } \\
\text { sensu stricto }\end{array}$ & $\begin{array}{l}\text { Partially } \\
\text { cleared } \\
\text { cerrado }\end{array}$ & $\begin{array}{c}\text { Shrubby } \\
\text { pasture }\end{array}$ & $\begin{array}{l}\text { Cleared } \\
\text { pasture }\end{array}$ \\
\hline Total richness & 49 & 24 & 20 & 11 \\
\hline Birds that use mainly herbs & 10 & 8 & 9 & 7 \\
\hline Birds that use mainly shrubs & 11 & 5 & 4 & 1 \\
\hline Birds that use mainly trees & 28 & 11 & 7 & 3 \\
\hline \multicolumn{5}{|l|}{ Relative abundance } \\
\hline Birds that use mainly herbs & $4.00 \pm 2.90$ & $19.60 \pm 10.01$ & $16.32 \pm 7.61$ & $11.91 \pm 5.13$ \\
\hline Birds that use mainly shrubs & $9.15 \pm 6.93$ & $6.10 \pm 4.50$ & $1.75 \pm 2.18$ & $0.38 \pm 0.61$ \\
\hline Birds that use mainly trees & $18.56 \pm 9.95$ & $3.70 \pm 3.90$ & $2.15 \pm 3.46$ & $0.34 \pm 0.97$ \\
\hline
\end{tabular}

\section{Comparisons among preserved and disturbed cerrado sensu stricto stands}

Cleared pastures This habitat held $11(22 \%)$ species recorded in cerrado sensu stricto plots. Among them were $70 \%$ of cerrado sensu stricto birds strongly dependent on the herbaceous stratum, $9 \%$ of species that primarily use shrubs and $11 \%$ of arboreal species (Table 3). Of these 11 species, three were more abundant in pastures, five were more abundant in preserved cerrado sensu stricto and three showed no significant differences between these two habitats (Appendix 3). In comparison to preserved cerrado sensu stricto, these pastures had greater values of relative abundance of cerrado sensu stricto birds that primarily use the herbaceous stratum $(H=42.13, P<0.01)$, but lower values for birds more dependent on shrubs $(H=46.22, P<0.01)$ and on trees $(H=44.48, P<0.01)$ (Table 3).

These pastures attracted five other species not found in preserved cerrado sensu stricto plots. They include one granivorous species (Sicalis citrina) and four insectivorous birds commonly recorded in habitats with smaller wood layer (CC, CS and CL) (Appendix 3).

Shrubby pastures A total of 34 species was recorded in this habitat. Among them are $94 \%$ of species present in CP, 19 more species than recorded in cleared pastures. This increase of about $120 \%$ in species richness is due mainly to species that depend strongly on the shrub stratum, like Neothraupis fasciata, Synnalaxis albescens and the Rufous-winged Antshrike Thamnophilus torquatus. Shrubby pastures had greater abundances of cerrado sensu stricto birds that depend on trees $(H=8.76, P<0.01)$ and shrubs $(H=8.10, P<0.01)$ than cleared pastures (Table 3$)$.

This habitat had $20(40 \%)$ of the species recorded in sites of cerrado sensu stricto. This includes $90 \%$ of cerrado sensu stricto birds that use primarily the herbaceous stratum, $36 \%$ of species that strongly depend on shrubs and $25 \%$ of the arboreal species (Table 3). Of these 20 common species, five were more abundant in shrubby pastures, four were more abundant in preserved cerrado sensu stricto and eight showed no significative differences between these two habitats.

In relation to the abundance of cerrado sensu stricto birds, shrubby pastures had greater values for birds strongly dependent on herbs $(H=50.40, P<0.01)$, but lower values for birds more dependent on shrubs $(H=39.82, P<0.01)$ and on trees $(H=54.08, P<0.01)$ than cerrado sensu stricto (Table 3$)$. 
Partially cleared cerrado This habitat held $87 \%$ of species present in cleared pastures and $76 \%$ of species recorded in shrubby pastures. Of the 37 species present in partially cleared cerrado, ten did not occur in pastures, being those species that explore the arboreal and shrubby strata. The abundance of cerrado sensu strcito birds that depend on trees $(H=6.01, P<0.01)$ and shrubs $(H=22.80, P<$ 0.01) was significantly greater in this site than in shrubby pastures.

This site supported $25(50 \%)$ of the species recorded in cerrado sensu stricto plots. Among them are $80 \%$ of cerrado sensu stricto birds that use the lower stratum, $45 \%$ of species that strongly depend on shrubs and $39 \%$ of the arboreal species (Table 3). In relation to the abundance of cerrado sensu stricto birds, this site held more birds that depend on the herbaceous stratum $(H=42.13, P<0.01)$ and lower values of abundance of birds strongly dependent on shrubs $(H=4.96$, $P<0.01)$ and on trees $(H=39.29, P<0.01)$ (Table 3 ).

\section{Occurrence of Cerrado endemic species in the disturbed sites}

Of the 18 Cerrado endemic species which occur in Distrito Federal (Silva 1995) 10 were recorded in the 12 study sites. The partially cleared cerrado held six endemic species and only three endemic species occurred in shrubby pastures. Cleared pastures had only one endemic species.

The Yellow-faced Parrot Amazona xanthops, Dwarf Tinamou Taoniscus nanus, Streaked Saltator Saltator atricollis and the Blue Finch Porphyrospiza caerulescens were restricted to preserved sites. The Campo Miner Geobates poecilopterus and the Coal-crested Finch Charitospiza eucosma were scarce and recorded only in the partially cleared cerrado.

The other four species occurred in both preserved and disturbed habitats. The Collared Crescent-chest Melanopareia torquata occurred in shrubby pastures with lower abundance than in campo cerrado $(H=17.29, P<0.01)$ and cerrado sensu stricto $(H=18.58, P<0.01)$. Its abundance in PCC was greater than in cerrado sensu stricto $(H=6.21, P<0.01)$ and showed no difference in relation to campo cerrado $(H=2.57, P<0.10)$. Neothraupis fasciata was significantly more abundant in the partially cleared cerrado than in cerrado sensu stricto $(H=10.37, P<0.01)$ and campo cerrado $(H=6.52, P<0.01)$, in which this species occurred in greater abundances than in shrubby pastures $(H=5.45, P<0.02$ and $H=7.15, P<$ o.01, respectively). Cypsnagra hirundinacea occurred only in the partially cleared cerrado with abundance significantly lower than in campo cerrado $(H=5.01, P<$ o.02) and campo sujo $(H=3.98, P<0.046)$. Cyanocorax cristatellus occurred in all disturbed habitats with greater abundances in those with more complex vegetation. Its abundance in the partially cleared cerrado was significantly lower than in cerrado sensu stricto $(H=14.32, P<0.01)$, but showed no difference in relation to campo cerrado $(H=0.04, P<0.83)$.

\section{Discussion}

Pastures and grasslands

In comparison to natural grasslands, pastures held communities with similar species richness, in agreement with other studies comparing habitats of similar structure (e.g. Karr 1971). However, their avifaunas were very distinct, maybe 
due to grass species composition, as floristics can strongly contribute to the structure of bird communities (Rotenberry 1985, MacNally 1990). Pastures had only about $50 \%$ of species recorded in natural grasslands with similar structure. The greatest differences between pastures and grasslands were in pastures not having obligate grassland birds, nor those that also use campo cerrado, such as seedeaters and birds with diets slightly or not dependent on seeds, such as Culicivora caudacuta, Alectrurus tricolor and Buteogallus meridionalis (unpubl. data).

Some birds that occur in the entire open gradient, like Emberizoides herbicola, Rhynchotus rufescens and Alopochelidon fucata were more abundant in natural grasslands than in pastures, highlighting the unsuitability of pastures for most bird species. A few species, such as Volatinia jacarina, Ammodramus humeralis, Crypturellus parvirostris, Nothura maculosa and Sicalis citrina, were apparently adapted to exotic seeds.

Several factors may contribute to the distribution and abundance of birds in pastures and grasslands: (1) floristic composition, pastures often having a single grass species, while high grass species richness is found in natural grasslands (Filgueiras 1991); (2) associated grassland resources, such as the invertebrate fauna, may be very different from those of pastures; (3) the structure of native and exotic herbs are not so similar when considered in detail and this may inhibit nest construction and dispersion for grassland birds; (4) exotic grasses, e.g. Melinis, have sticky blades that can damage feathers of ground-foraging species; (5) the lower herb cover of pastures could also contribute to the reduction in the number of some grassland species, though birds such as Cistothorus platensis and Alectrurus tricolor do not occur in pastures with denser exotic herb cover found in the region (pers. obs.); (6) cattle trampling probably did not have a strong effect on communities, as the pastures were apparently abandoned.

\section{Preserved and disturbed cerrado sensu stricto patches}

Disturbed sites of cerrado sensu stricto were characterized by a seedeater, Volatinia jacarina, in great abundance. This species occurs at low densities in preserved Cerrado habitats (this study, Figueiredo 1991, Ferreira 1996) and appears to be highly adapted to exotic grasses, because its high abundance in disturbed sites was not affected by the density of shrubs and trees.

The loss of cerrado sensu stricto species in cleared pastures is due mainly to species dependent on shrubs and trees, which were the most modified portions of vegetation. This result is in accordance with other works (Woinarski 1990, Johns 1991, Woinarski 1993, Mason 1996), showing that changes in bird communities depend on the type of habitat disturbance. The reduction of the shrub and tree cover probably leads to the loss of resources for nesting, food and roosting, mainly for frugivorous and insectivorous birds.

On the other hand, cleared pastures supported most cerrado sensu stricto bird species strongly dependent on the herbaceous stratum, despite the complete substitution of grass species by exotic cover. Thus, these birds appear to be more adapted to exotic grasses than most grassland birds. These distinct patterns probably result from the loss of strong bird-habitat associations, as commonly observed in other habitats (Rotenberry and Wiens 1980, Kikkawa 1982, Bibby et al. 1985, Brown and Stillman 1993). Further, the abundance of some species 
strongly dependent on herbs changed dramatically within the gradient of disturbed sites, despite the herbaceous stratum being similar in these sites. Because most birds are not restricted to only one stratum, strong changes in specific strata can influence the presence and abundance of species that depend mainly on other sectors of vegetation.

The bird communities in disturbed areas represent a minimal impact of reduction of tree and shrub cover in cerrado sensu stricto stands. First, the disturbed plots are situated adjacent to a preserved cerrado sensu stricto patch, separated only by a road. This proximity may increase the species richness of birds near the edge of disturbed sites as a result of a process similar to that of the matrix effect in altered landscapes (e.g. Bierregaard and Stouffer 1997). Second, many forest species that are often found in cerrado sensu stricto, such as the Streaked Flycatcher Myodynastes maculatus, the Green-winged Saltator Saltator similis and the Guira Tanager Hemithraupis guira, were not recorded in SS1 and SS2. The points were located far from gallery forests, reducing the probability of recording these species. Thus representation of cerrado sensu stricto species in disturbed habitats would be lower if other species known to use this habitat in the region were considered.

Comparisons among bird communities of preserved and disturbed cerrado sensu stricto stands suggest that, as regrowth of shrubs and trees increases, more species dependent on tree and shrubs could be favoured. Abundance of arboreal species in the partially cleared cerrado is still low when compared with preserved sites. However, this vegetation complexity appears to be suitable for some species, including the endemics Neothraupis fasciata and Melanopareia torquata. Restoration of disturbed cerrado sensu stricto may provide suitable habitat for more arboreal birds, in a similar way to woodland regrowth in other regions. Other species in the regional habitat matrix would also benefit, because there are movements of birds among Cerrado habitats (Cavalcanti 1992).

The strong correlation between bird communities of preserved study sites suggests that conservation and management programmes must consider not only the vegetation structure but also the floristic composition of habitats. Extensive programmes of forest restoration through the plantation of certain native fruit tree species provide better habitat quality (Lamb et al. 1997) and could be applied to disturbed plots of cerrado sensu stricto.

\section{Conservation issues}

Traditional cleared pastures had very few $(25 \%)$ species of cerrado sensu stricto. Shrubby pastures, however, were richer by about $120 \%$ in relation to cleared ones. The increase in vegetation complexity provided conditions for 20 more species, such as Neothraupis fasciata, Melanopareia torquata and Synallaxis albescens, that represent together $40 \%$ of species recorded in cerrado sensu stricto. Thus, programmes that provide incentives for regrowth of shrub and tree cover in cleared pastures could be of great importance for the maintenance of richer bird communities. This study did not determine if bird species can survive in shrubby pastures independently of adjacent preserved stands. However, pastures could function more efficiently as corridors for bird species if they have as many shrubs and trees as possible, but without interfering with cattle movements and grazing. 
Despite having more diverse bird communities than cleared pastures, shrubby pastures did not harbour great richness and abundance of Cerrado endemic species. Considering all disturbed habitats, most recorded endemics were restricted to the partially cleared cerrado. This habitat appears to provide suitable conditions for more endemics than pastures, specially for Neothraupis fasciata and $\mathrm{Mel}$ anopareia torquata, that were more abundant in this disturbed habitat than in the preserved ones.

Cleared and shrubby pastures held bird communities very dissimilar to those of natural grasslands. They do not support obligate grassland species, such as Cistothorus platensis, Alectrurus tricolor and Coryphaspiza melanotis, which appear to depend on the native grasses and their associated invertebrate fauna. Severe modifications in the soil structure and chemistry impede recovery of native grasses in abandoned agricultural land, making restoration extremely difficult and expensive. Thus, efforts to conserve campo limpo and campo sujo bird species must be focused in an urgent programme to locate non protected areas dominated by these habitats, and to convert them to conservation reserves.

Another threat to grassland birds is the possible negative effect of grassland invasion by exotic grasses that is occurring in the Cerrado. Introduced species used in pastures, such as Brachiaria sp. and Melinis minutiflora, have been currently found in several Cerrado areas, including conservation reserves (Berardi 1994, Klink 1996, Pivello et al. 1999a,b). Exotic grasses could drastically reduce populations of grassland bird species. Volatinia jacarina and Sicalis citrina, species that use mainly the herbaceous stratum and feed on herb seeds, were much more abundant in pastures than in natural grasslands with similar structure. In preserved Cerrado areas, most individuals of these two species are often recorded within a narrow band along roads (pers. obs.). This pattern of occurrence probably reflects their adaptation to exotic grasses species, that invade along roads. Censuses of these birds may indicate exotic grassland invasion.

Finally, despite lower bird species richness than forests, open habitats are used by almost half of the Cerrado bird species, including several endemics (Silva 1995, Stotz et al. 1996). Further, non-wetland open habitats are suffering intense destruction by large-scale mechanized agriculture (Dias 1993). In some regions, such as the state of São Paulo, destruction of these physiognomies has led to a drastic loss of Cerrado bird species (Willis and Oniki 1992). Thus, non-wetland open physiognomies must receive more conservation attention and large intact areas of the Cerrado mosaic, where they are dominant, must be urgently identified and converted to protected reserves. Open habitat birds could be protected if regulations that protect gallery forests are expanded to include open habitats along forest edges. These would also insure the presence of stopovers for migrant species and corridors of open habitats connecting Cerrado reserves.

\section{Acknowledgements}

We thank the Conselho Nacional de Desenvolvimento Científico e Tecnológico (CNPq) for a fellowship to D.P.T., the Fundação de Apoio à Pesquisa do Distrito 
Federal (FAPDF) for a research grant, and the Universidade de Brasília (UnB) and Jardim Botânico de Brasília for the use of their field facilities. This work is part of D.P.T.'s MSc dissertation in ecology at UnB, supervised by R.B.C.. G. R. Colli, E. O. Willis, R. H. F. Macedo and W. M. Tomas made important suggestions on analysis. J. D. Hay provided advice on the vegetation sampling methods. This manuscript was improved by important comments from J. M. C. da Silva and C. A. Klink.

Appendix 1. Relative abundance (individuals per sample) of bird species recorded in campo limpo and cleared pasture stands, with information on occurrence in cerrado sensu lato habitats and values of the Kruskal-Wallis test $(H$ and $P$ ). Species were ranked according to their abundance in campo limpo. The habitats are cerrado sensu stricto (ss), campo cerrado (cc), campo sujo (cs) and campo limpo (cl).

\begin{tabular}{|c|c|c|c|c|c|}
\hline Species & $\begin{array}{l}\text { Campo } \\
\text { limpo }\end{array}$ & $\begin{array}{l}\text { Cleared } \\
\text { pasture }\end{array}$ & Habitats & $H$ & $P$ \\
\hline $\begin{array}{l}\text { Grass Wren Cistothorus platensis } \\
\text { Wedge-tailed Grass-finch Emberizoides }\end{array}$ & $5 \cdot 41$ & o & $\mathrm{cl}, \mathrm{cs}$ & 64.00 & $<0.01$ \\
\hline $\begin{array}{l}\text { herbicola } \\
\text { Tawny-headed Swallow Alopochelidon }\end{array}$ & 2.31 & 0.03 & $\mathrm{cl}, \mathrm{cs}, \mathrm{cc}, \mathrm{ss}$ & $45 \cdot 97$ & $<0.01$ \\
\hline fucata & 1.31 & 0.56 & $\mathrm{cl}, \mathrm{cs}, \mathrm{cc}$ & $5 \cdot 38$ & 0.02 \\
\hline Cock-tailed Tyrant Alectrurus tricolor & 1.31 & o & $\mathrm{cl}, \mathrm{cs}$ & $19 \cdot 59$ & $<0.01$ \\
\hline $\begin{array}{l}\text { Spotted Nothura Nothura maculosa } \\
\text { Red-winged Tinamou Rhynchotus }\end{array}$ & 0.97 & 0.63 & $\mathrm{cl}, \mathrm{cs}, \mathrm{cc}, \mathrm{ss}$ & 0.25 & 0.62 \\
\hline $\begin{array}{l}\text { rufescens } \\
\text { Sharp-tailed Grass-tyrant Culicivora }\end{array}$ & 0.91 & 0.09 & $\mathrm{cl}, \mathrm{cs}, \mathrm{cc}, \mathrm{ss}$ & 15.95 & $<0.01$ \\
\hline caudacuta & 0.84 & o & $\mathrm{cl}, \mathrm{cs}, \mathrm{cc}$ & 6.62 & 0.01 \\
\hline $\begin{array}{l}\text { White-vented Violetear Colibri serrirostris } \\
\text { Grassland Sparrow Ammodramus }\end{array}$ & 0.78 & 0.38 & $\mathrm{cl}, \mathrm{cs}, \mathrm{cc}, \mathrm{ss}$ & 3.14 & 0.76 \\
\hline $\begin{array}{l}\text { humeralis } \\
\text { Small-billed Tinamous Crypturellus }\end{array}$ & 0.59 & 1.16 & $\mathrm{cl}, \mathrm{cs}, \mathrm{cC}, \mathrm{ss}$ & 4.02 & 0.045 \\
\hline parvirostris & 0.34 & 0.94 & $\mathrm{cl}, \mathrm{cs}, \mathrm{cc}, \mathrm{ss}$ & 9.04 & $<0.01$ \\
\hline $\begin{array}{l}\text { Stripe-tailed Yellow-finch Sicalis citrina } \\
\text { Black Masked Finch Coryphaspiza }\end{array}$ & 0.25 & 0.91 & $\mathrm{cl}, \mathrm{cs}, \mathrm{cc}$ & 6.03 & 0.01 \\
\hline melanotis & 0.22 & o & $\mathrm{cl}, \mathrm{cs}$ & 7.86 & $<0.01$ \\
\hline Burrowing Owl Speotyto cunicularia & 0.19 & 0.06 & $\mathrm{cl}, \mathrm{cs}, \mathrm{cc}$ & 1.07 & 0.30 \\
\hline Brown-chested Martin Phaeoprogne tapera & 0.13 & o & $\mathrm{cl}, \mathrm{cs}$ & & \\
\hline Dwarf Tinamou Taoniscus nanus & 0.06 & o & $\mathrm{cl}, \mathrm{cs}$ & & \\
\hline Plumbeous Seedeater Sporophila plumbea & 0.03 & 0.09 & $\mathrm{cl}, \mathrm{CS}, \mathrm{CC}, \mathrm{ss}$ & & \\
\hline Horned Sungem Heliactin cornuta & 0.03 & o & $\mathrm{cl}, \mathrm{cs}, \mathrm{cc}, \mathrm{ss}$ & & \\
\hline $\begin{array}{l}\text { American Kestrel Falco sparverius } \\
\text { Double-collared Seedeater Sporophila }\end{array}$ & 0.03 & o & $\mathrm{cl}, \mathrm{cs}$ & & \\
\hline caerulescens & 0.03 & o & $\mathrm{cl}$ & & \\
\hline Blue-black Grassquit Volatinia jacarina & $\mathrm{o}$ & 8.97 & Cs, ss & 56.47 & $<0.01$ \\
\hline Gray Monjita Xolmis cinerea & o & 0.34 & $\mathrm{CS}, \mathrm{CC}$ & 10.47 & $<0.01$ \\
\hline Curl-crested Jay Cyanocorax cristatellus & o & 0.16 & $\mathrm{CC}, \mathrm{ss}$ & & \\
\hline White-tailed Kite Elanus leucurus & $\mathrm{O}$ & 0.16 & $\mathrm{CC}, \mathrm{ss}$ & $5 \cdot 42$ & 0.02 \\
\hline $\begin{array}{l}\text { Southern Lapwing Vanellus chilensis } \\
\text { Yellow-headed Caracara Milvago }\end{array}$ & o & 0.06 & & & \\
\hline chimachima & $\mathrm{O}$ & 0.03 & $\mathrm{CC}, \mathrm{sS}$ & & \\
\hline
\end{tabular}


Appendix 2. Relative abundance (individuals per sample) of bird species recorded in campo sujo and shrubby pasture stands, with information on occurrence in cerrado sensu lato habitats and values of the Kruskal-Wallis test $(H$ and $P)$. Species were ranked according to their abundance in campo sujo. The habitats are cerrado sensu stricto (ss), campo cerrado (cc), campo sujo (cs) and campo limpo $(\mathrm{cl})$.

\begin{tabular}{|c|c|c|c|c|c|}
\hline Species & $\begin{array}{l}\text { Campo } \\
\text { sujo }\end{array}$ & $\begin{array}{l}\text { Shrubby } \\
\text { pasture }\end{array}$ & Habitat & $H$ & $P$ \\
\hline $\begin{array}{l}\text { Grass Wren Cistothorus platensis } \\
\text { Wedge-tailed Grass-finch Emberizoides }\end{array}$ & 4.67 & 0.03 & $\mathrm{cl}, \mathrm{cs}$ & 53.20 & $<0.01$ \\
\hline $\begin{array}{l}\text { herbicola } \\
\text { Grassland Sparrow Ammodramus }\end{array}$ & 2.58 & 1.33 & $\mathrm{cl}, \mathrm{cs}, \mathrm{cc}, \mathrm{ss}$ & $7 \cdot 45$ & $<0.01$ \\
\hline humeralis & 1.65 & 2.15 & $\mathrm{cl}, \mathrm{cs}, \mathrm{cc}, \mathrm{ss}$ & 0.42 & 0.52 \\
\hline Cock-tailed Tyrant Alectrurus tricolor & 1.46 & o & $\mathrm{cl}, \mathrm{CS}$ & 39.88 & $<0.01$ \\
\hline $\begin{array}{l}\text { Campo Flicker Colaptes campestris } \\
\text { Tawny-headed Swallow Alopochelidon }\end{array}$ & 1.33 & 0.75 & $\mathrm{CS}, \mathrm{CC}, \mathrm{sS}$ & 2.20 & 0.14 \\
\hline $\begin{array}{l}\text { fucata } \\
\text { Sharp-tailed Grass-tyrant Culicivora }\end{array}$ & 1.15 & 0.25 & $\mathrm{cl}, \mathrm{cs}, \mathrm{cc}$ & 0.13 & 0.71 \\
\hline $\begin{array}{l}\text { caudacuta } \\
\text { Red-winged Tinamou Rhynchotus }\end{array}$ & 1.13 & 0.30 & $\mathrm{cl}, \mathrm{cs}, \mathrm{cc}$ & 3.88 & 0.049 \\
\hline rufescens & 1.00 & 0.18 & $\mathrm{cl}, \mathrm{Cs}, \mathrm{cc}, \mathrm{ss}$ & 15.84 & 0.01 \\
\hline $\begin{array}{l}\text { White-vented Violetear Colibri serrirostris } \\
\text { White-rumped Tanager Cypsnagra }\end{array}$ & 0.96 & 0.65 & $\mathrm{cl}, \mathrm{cs}, \mathrm{cc}, \mathrm{ss}$ & 0.98 & 0.32 \\
\hline hirundinacea & 0.85 & o & $\mathrm{CS}, \mathrm{CC}$ & 13.87 & $<0.01$ \\
\hline Spotted Nothura Nothura maculosa & 0.56 & 0.58 & $\mathrm{cl}, \mathrm{Cs}, \mathrm{cC}, \mathrm{ss}$ & 0.17 & 0.68 \\
\hline Horned Sungem Heliactin cornuta & 0.46 & o & $\mathrm{cl}, \mathrm{Cs}, \mathrm{cc}, \mathrm{ss}$ & $17 \cdot 56$ & $<0.01$ \\
\hline $\begin{array}{l}\text { Capped Seedeater Sporophila bouvreuil } \\
\text { White-rumped Swallow Tachycineta }\end{array}$ & 0.40 & $\mathrm{o}$ & Cs & $7 \cdot 33$ & $<0.01$ \\
\hline leucorrhoa & 0.35 & $\mathrm{O}$ & $\mathrm{CS}, \mathrm{CC}, \mathrm{sS}$ & & \\
\hline Turquoise-fronted Parrot Amazona aestiva & 0.29 & o & $\mathrm{CS}, \mathrm{CC}, \mathrm{sS}$ & & \\
\hline Stripe-tailed Yellow-finch Sicalis citrina & 0.23 & 1.30 & $\mathrm{cl}, \mathrm{Cs}, \mathrm{cc}$ & 16.13 & $<0.01$ \\
\hline Plumbeous Seedeater Sporophila plumbea & 0.21 & 1.08 & $\mathrm{cl}, \mathrm{Cs}, \mathrm{cc}, \mathrm{ss}$ & 1.59 & 0.21 \\
\hline Savanna Hawk Buteogallus meridionalis & 0.17 & o & cs & 6.34 & 0.01 \\
\hline Gray Monjita Xolmis cinerea & 0.17 & 0.50 & $\mathrm{CS}, \mathrm{CC}$ & 6.11 & 0.01 \\
\hline Fork-tailed Flycatcher Tyrannus savana & 0.17 & 0.05 & $\mathrm{CS}, \mathrm{CC}, \mathrm{sS}$ & 1.38 & 0.24 \\
\hline $\begin{array}{l}\text { White Woodpecker Melanerpes candidus } \\
\text { Small-billed Tinamou Crypturellus }\end{array}$ & 0.17 & $\mathrm{O}$ & Cs & & \\
\hline parvirostris & 0.15 & 0.83 & $\mathrm{cl}, \mathrm{cs}, \mathrm{cc}, \mathrm{ss}$ & 17.88 & $<0.01$ \\
\hline $\begin{array}{l}\text { Burrowing Owl Speotyto cunicularia } \\
\text { Black Masked Finch Coryphaspiza }\end{array}$ & 0.13 & 0.13 & $\mathrm{cl}, \mathrm{cs}, \mathrm{cc}$ & 1.82 & 0.18 \\
\hline melanotis & 0.13 & $\mathrm{O}$ & $\mathrm{cl}, \mathrm{cs}$ & & \\
\hline Blue-black Grassquit Volatinia jacarina & 0.08 & 10 & Cs, ss & 72.61 & $<0.01$ \\
\hline Crested Caracara Polyborus plancus & 0.08 & 0.08 & $\mathrm{CS}, \mathrm{CC}, \mathrm{sS}$ & & \\
\hline Brown-chested Martins Phaeoprogne tapera & 0.08 & 0.03 & $\mathrm{cl}, \mathrm{cs}$ & & \\
\hline Plain-crested Elaenia Elaenia cristata & 0.08 & o & $\mathrm{CS}, \mathrm{CC}, \mathrm{sS}$ & & \\
\hline $\begin{array}{l}\text { Yellow-faced Parrot Amazona xanthops } \\
\text { Swallow-tailed Hummingbird }\end{array}$ & 0.08 & $\mathrm{o}$ & $\mathrm{CS}, \mathrm{CC}, \mathrm{ss}$ & & \\
\hline $\begin{array}{l}\text { Eupetonema macroura } \\
\text { Pale-breasted Spinetail Synallaxis }\end{array}$ & 0.08 & $\mathrm{O}$ & CS & & \\
\hline albescens & 0.04 & 0.40 & $\mathrm{CS}, \mathrm{CC}, \mathrm{SS}$ & 9.03 & $<0.01$ \\
\hline $\begin{array}{l}\text { Grassland Yellow-finch Sicalis luteola } \\
\text { Blue-and-white Swallow Notiochelidon }\end{array}$ & 0.04 & 0.05 & $\mathrm{CS}, \mathrm{CC}, \mathrm{sS}$ & & \\
\hline cyanoleuca & 0.04 & o & $\mathrm{CS}, \mathrm{CC}$ & & \\
\hline Dwarf Tinamou Taoniscus nanus & 0.04 & o & $\mathrm{cl}, \mathrm{cs}$ & & \\
\hline Streamer-tailed Tyrant Gubernetes yetapa & 0.04 & $\mathrm{o}$ & cs & & \\
\hline American Kestrel Falco sparverius & 0.02 & 0.03 & $\mathrm{cl}, \mathrm{cs}$ & & \\
\hline Barn Owl Tyto alba & 0.02 & $\mathrm{o}$ & CS & & \\
\hline
\end{tabular}


Appendix 2. Continued.

\begin{tabular}{|c|c|c|c|c|c|}
\hline Species & $\begin{array}{l}\text { Campo } \\
\text { sujo }\end{array}$ & $\begin{array}{l}\text { Shrubby } \\
\text { pasture }\end{array}$ & Habitat & $H$ & $P$ \\
\hline Blue Finch Porphyrospiza caerulescens & 0.02 & $\mathrm{O}$ & cS & & \\
\hline $\begin{array}{l}\text { Curl-crested Jay Cyanocorax cristatellus } \\
\text { White-banded Tanager Neothraupis }\end{array}$ & o & 0.75 & $\mathrm{CC}, \mathrm{ss}$ & 6.36 & 0.01 \\
\hline fasciata & o & 0.53 & $\mathrm{CC}, \mathrm{sS}$ & & \\
\hline White-tailed Kite Elanus leucurus & $\mathrm{o}$ & 0.25 & $\mathrm{CC}, \mathrm{ss}$ & 10.56 & $<0.01$ \\
\hline Peach-fronted Parakeet Aratinga aurea & $\mathrm{o}$ & 0.23 & $\mathrm{CC}, \mathrm{ss}$ & & \\
\hline $\begin{array}{l}\text { Spinetail Synallaxis sp } \\
\text { Collared Crescent-chest Melanopareia }\end{array}$ & o & 0.18 & $\mathrm{CC}, \mathrm{ss}$ & 6.36 & 0.01 \\
\hline $\begin{array}{l}\text { torquata } \\
\text { Rufous-winged Antshrike Thamnophilus }\end{array}$ & o & 0.15 & $\mathrm{CC}, \mathrm{sS}$ & $7 \cdot 73$ & $<0.01$ \\
\hline torquatus & $\mathrm{O}$ & 0.13 & ss & 6.36 & 0.01 \\
\hline $\begin{array}{l}\text { Roadside Hawk Buteo magnirostris } \\
\text { Chalk-browned Mockingbird Mimus }\end{array}$ & o & 0.05 & CC, ss & & \\
\hline $\begin{array}{l}\text { saturninus } \\
\text { Yellow-headed Caracara Milvago }\end{array}$ & $\mathrm{o}$ & 0.05 & $\mathrm{CC}$ & & \\
\hline chimachima & $\mathrm{o}$ & 0.05 & CC, ss & & \\
\hline $\begin{array}{l}\text { Campo Miner Geobates poecilopterus } \\
\text { Rufous-collared Sparrow Zonotrichia }\end{array}$ & o & 0.05 & & & \\
\hline capensis & $\mathrm{o}$ & 0.05 & & & \\
\hline Striped Owl Rhinoptynx clamator & o & 0.03 & & & \\
\hline
\end{tabular}

Appendix 3. Relative abundance (individuals per sample) of bird species recorded in preserved and disturbed sites of cerrado sensu stricto, with information on strata preference and occurrence in cerrado sensu lato habitats. Species were ranked according to their abundance in cerrado sensu stricto. The habitats are: cerrado sensu stricto (SS), partially cleared cerrado (PCC), shrubby pasture (SP) and cleared pasture (CP). The strata are tree (T), shrubs $(\mathrm{S})$ and herbs $(\mathrm{H})$.

\begin{tabular}{|c|c|c|c|c|c|}
\hline Species & $\begin{array}{l}\text { Main } \\
\text { strata }\end{array}$ & SS & PCC & SP & $\mathrm{CP}$ \\
\hline Curl-crested Jay Cyanocorax cristatellus & $\mathrm{T}$ & $4 \cdot 40^{\mathrm{a}}$ & $1.27^{\mathrm{b}}$ & $0.75^{\mathrm{b}}$ & $0.16^{\mathrm{b}}$ \\
\hline Turquoise-fronted Parrot Amazona aestiva & $\mathrm{T}$ & $3.67^{\mathrm{a}}$ & $0.17^{\mathrm{b}}$ & o & o \\
\hline Common Thornbird Phacellodomus rufifrons & $\mathrm{S}$ & $2.89^{a}$ & o & o & o \\
\hline Lesser Elaenia Elaenia chiriquensis & S & $2.33^{\mathrm{a}}$ & $\mathrm{o}$ & o & o \\
\hline Suiriri Flycatcher Suiriri suiriri & $\mathrm{T}$ & $2.04^{a}$ & $\mathrm{O}$ & o & o \\
\hline White-banded Tanager Neothraupis fasciata & S & $1.71^{\mathrm{a}}$ & $3 \cdot 40^{\mathrm{b}}$ & $0.53^{\mathrm{b}}$ & o \\
\hline House Wren Troglodytes aedon & $\mathrm{T}$ & $1.28^{\mathrm{a}}$ & $0.33^{\mathrm{b}}$ & o & o \\
\hline Small-billed Tinamou Crypturellus parvirostris & $\mathrm{H}$ & $1.25^{\mathrm{a}}$ & $0.90^{\mathrm{a}}$ & $0.83^{\mathrm{a}}$ & $0.94^{\mathrm{a}}$ \\
\hline Southern Beardless-tyrannulet Camptostoma & & & & & \\
\hline obsoletum & $\mathrm{T}$ & $1.18^{\mathrm{a}}$ & $0.20^{\mathrm{b}}$ & $\mathrm{O}$ & $\mathrm{O}$ \\
\hline Plain-crested Elaenia Elaenia cristata & S & $0.88^{\mathrm{a}}$ & $\mathrm{O}$ & $\mathrm{O}$ & o \\
\hline Collared Crescent-chest Melanopareia torquata & $\mathrm{H}$ & $0.81^{\mathrm{a}}$ & $1.13^{\mathrm{b}}$ & $0.15^{b}$ & o \\
\hline Glittering-throated Emerald Amazilia fimbriata & $\mathrm{T}$ & $0.81^{\mathrm{a}}$ & $0.13^{\mathrm{b}}$ & $\mathrm{O}$ & o \\
\hline Campo Flicker Colaptes campestris & $\mathrm{T}$ & $0.79^{\mathrm{a}}$ & $1.10^{\mathrm{a}}$ & $0.75^{\mathrm{a}}$ & o \\
\hline White-vented Violetear Colibri serrirostris & S & $0.64^{a}$ & $1.27^{\mathrm{b}}$ & $0.65^{\mathrm{a}}$ & $0.38^{\mathrm{a}}$ \\
\hline $\begin{array}{l}\text { Narrow-billed Woodcreeper Lepidocolaptes agu- } \\
\text { strirostris }\end{array}$ & $\mathrm{T}$ & $0.56^{\mathrm{a}}$ & $\mathrm{O}$ & $\mathrm{O}$ & $\mathrm{O}$ \\
\hline Canary-winged Parakeet Brotogeris chiriri & $\mathrm{T}$ & $0.53^{\mathrm{a}}$ & o & o & $\mathrm{o}$ \\
\hline Picazuro Pigeon Columba picazuro & $\mathrm{T}$ & $0.51^{\mathrm{a}}$ & $0.10^{\mathrm{b}}$ & o & o \\
\hline Peach-fronted Parakeet Aratinga aurea & $\mathrm{T}$ & $0.49^{\mathrm{a}}$ & $0.27^{\mathrm{a}}$ & $0.23^{\mathrm{a}}$ & o \\
\hline Checkered Woodpecker Dendrocopus mixtus & $\mathrm{T}$ & $0.11^{\mathrm{a}}$ & o & o & o \\
\hline Red-winged Tinamou Rhynchotus rufescens & $\mathrm{H}$ & $0.44^{\mathrm{a}}$ & $0.20^{\mathrm{a}}$ & $0.18^{\mathrm{b}}$ & $0.09^{\mathrm{b}}$ \\
\hline Yellow-bellied Elaenia Elaenia flavogaster & $\mathrm{T}$ & $0.68^{\mathrm{a}}$ & o & o & $\mathrm{o}$ \\
\hline
\end{tabular}


Appendix 3. Continued.

\begin{tabular}{|c|c|c|c|c|c|}
\hline Species & $\begin{array}{l}\text { Main } \\
\text { strata }\end{array}$ & SS & PCC & SP & $\mathrm{CP}$ \\
\hline White-eared Puffbird Nystalus chacuru & $\mathrm{T}$ & $0.43^{\mathrm{a}}$ & o & o & o \\
\hline Wedge-tailed Grass-finch Emberizoides herbicola & $\mathrm{H}$ & $0.42^{\mathrm{a}}$ & $0.50^{\mathrm{a}}$ & $1.33^{\mathrm{b}}$ & $0.03^{\mathrm{b}}-(-1.5)$ \\
\hline Red-legged Seriema Cariama cristata & $\mathrm{H}$ & $0.42^{\mathrm{a}}$ & o & o & o \\
\hline Pale-breasted Spinetail Synnalaxis albescens & S & $0.39^{\mathrm{a}}$ & $1.20^{\mathrm{b}}$ & $0.4 \mathrm{O}^{\mathrm{a}}$ & o \\
\hline Short-crested Flycatcher Myiarchus ferox & $\mathrm{T}$ & $0.29^{\mathrm{a}}$ & o & o & o \\
\hline Plumbeous seedeater Sporophila plumbea & $\mathrm{H}$ & $0.22^{\mathrm{a}}$ & $3.23^{\mathrm{b}}$ & $1.08^{\mathrm{b}}$ & $0.09^{\mathrm{a}}$ \\
\hline Grassland Sparrow Ammodramus humeralis & $\mathrm{H}$ & $0.21^{\mathrm{a}}$ & $1.70^{\mathrm{b}}$ & $2.15^{\mathrm{b}}$ & $1.16^{\mathrm{b}}$ \\
\hline White-tailed Kite Elanus leucurus & $\mathrm{T}$ & $0.19^{\mathrm{a}}$ & $0.10^{\mathrm{a}}$ & $0.25^{\mathrm{a}}$ & $0.16^{\mathrm{a}}$ \\
\hline Toco Toucan Ramphastos toco & $\mathrm{T}$ & $0.17^{\mathrm{a}}$ & o & o & o \\
\hline Roadside Hawk Buteo magnirostris & $\mathrm{T}$ & $0.13^{\mathrm{a}}$ & $0.07^{\mathrm{a}}$ & $0.05^{\mathrm{a}}$ & o \\
\hline Blue-black grassquit Volatinia jacarina & $\mathrm{H}$ & $0.11^{\mathrm{a}}$ & $11.83^{\mathrm{b}}$ & $10.00^{\mathrm{b}}$ & $8.97^{\mathrm{b}}$ \\
\hline Lineated Woodpecker Dryocopus lineatus & $\mathrm{T}$ & $0.11^{\mathrm{a}}$ & o & o & o \\
\hline Masked Gnatcatcher Polioptila dumicola & $\mathrm{T}$ & $0.11^{\mathrm{a}}$ & o & o & o \\
\hline Elaenia Elaenia sp I & $\mathrm{S}$ & $0.10^{\mathrm{a}}$ & o & o & o \\
\hline Spotted Nothura Nothura maculosa & $\mathrm{H}$ & $0.10^{\mathrm{a}}$ & $0.10^{\mathrm{a}}$ & $0.58^{\mathrm{b}}$ & $0.62^{\mathrm{b}}-(-1)(-1)$ \\
\hline Spinetail Synallaxis $s p$ & $\mathrm{~S}$ & $0.08^{\mathrm{a}}$ & $0.10^{\mathrm{a}}$ & $0.18^{\mathrm{a}}$ & o \\
\hline Yellow-faced Parrot Amazona xanthops & $\mathrm{T}$ & $0.08^{\mathrm{a}}$ & o & o & o \\
\hline Horned Sungem Heliactin cornuta & $\mathrm{S}$ & $0.06^{\mathrm{a}}$ & $0.13^{\mathrm{a}}$ & o & o \\
\hline Bran-colored Flycatcher Myiophobus fasciatus & $\mathrm{S}$ & $0.06^{\mathrm{a}}$ & o & o & o \\
\hline Elaenia sp 2 & $\mathrm{~T}$ & $0.06^{\mathrm{a}}$ & o & o & o \\
\hline White-rumped Swallow Tachycineta leucorrhoa & A & $0.04^{\mathrm{a}}$ & $0.07^{\mathrm{a}}$ & o & o \\
\hline Grassland Yellow-finch Sicalis luteola & $\mathrm{H}$ & $0.03^{\mathrm{a}}$ & o & $0.05^{\mathrm{a}}$ & o \\
\hline Aplomado Falcon Falco femoralis & $\mathrm{T}$ & $0.03^{\mathrm{a}}$ & o & o & o \\
\hline Tropical Screech-owl Otus choliba & $\mathrm{T}$ & $0.03^{\mathrm{a}}$ & o & o & o \\
\hline $\begin{array}{l}\text { Crimson-crested Woodpecker Campephilus mel- } \\
\text { anoleucus }\end{array}$ & $\mathrm{T}$ & $0.03^{\mathrm{a}}$ & o & o & o \\
\hline Black-throated Saltator Saltator atricollis & $\mathrm{H}$ & $0.03^{\mathrm{a}}$ & o & o & o \\
\hline Crested Caracara Polyborus plancus & $\mathrm{T}$ & $0.01^{\mathrm{a}}$ & $0.03^{\mathrm{a}}$ & $0.08^{\mathrm{a}}$ & $\mathrm{o}$ \\
\hline Versicolored Emerald Amazilia versicolor & $\mathrm{T}$ & $0.01^{\mathrm{a}}$ & o & o & o \\
\hline Yellow-headed Caracara Milvago chimachima & $\mathrm{T}$ & $0.01^{\mathrm{a}}$ & o & $0.05^{\mathrm{a}}$ & $0.03^{\mathrm{a}}$ \\
\hline Stripe-tailed Yellow-finch Sicalis citrina & & $\mathrm{O}^{\mathrm{a}}$ & $0.57^{\mathrm{b}}$ & $1.30^{\mathrm{b}}$ & $0.91^{\mathrm{b}}$ \\
\hline Gray Monjita Xolmis cinerea & & $\mathrm{O}^{\mathrm{a}}$ & $0.53^{\mathrm{b}}$ & $0.50^{\mathrm{b}}$ & $0.34^{\mathrm{b}}$ \\
\hline Tawny-headed Swallow Alopochelidon fucata & & $\mathrm{O}^{\mathrm{a}}$ & $0.50^{\mathrm{b}}$ & $0.25^{\mathrm{b}}$ & $0.56^{\mathrm{b}}$ \\
\hline Sharp-tailed Grass-tyrant Culicivora caudacuta & & $\mathrm{O}^{\mathrm{a}}$ & $0.93^{\mathrm{b}}$ & $0.30^{\mathrm{b}}$ & o \\
\hline $\begin{array}{l}\text { Rufous-winged Antshrike Thamnophilus tor- } \\
\text { quatus }\end{array}$ & & $\mathrm{O}^{\mathrm{a}}$ & $0.40^{\mathrm{b}}$ & $0.13^{\mathrm{b}}$ & o \\
\hline Burrowing Owl Speotyto cunicularia & & $\mathrm{O}^{\mathrm{a}}$ & $0.07^{\mathrm{b}}$ & $0.13^{\mathrm{b}}$ & $0.31^{\mathrm{a}}$ \\
\hline White-rumped Tanager Cypsnagra hirundinacea & & $\mathrm{O}^{\mathrm{a}}$ & $0.40^{\mathrm{b}}$ & o & o \\
\hline Capped Seedeater Sporophila bouvreuil & & $\mathrm{O}^{\mathrm{a}}$ & $0.30^{\mathrm{b}}$ & o & o \\
\hline Fork-tailed Flycatcher Tyrannus savanna & & $\mathrm{O}^{\mathrm{a}}$ & $0.20^{\mathrm{b}}$ & 0.05 & o \\
\hline Chalk-browned Mockingbird Mimus saturninus & & $\mathrm{O}^{\mathrm{a}}$ & $0.13^{\mathrm{a}}$ & 0.05 & o \\
\hline Yellow-chinned Spinetail Certhiaxis cinammo- & & & & & \\
\hline mea & & $\mathrm{O}^{\mathrm{a}}$ & 0.07 & o & $\mathrm{o}$ \\
\hline Coal-crested Finch Charitospiza euscoma & & $\mathrm{O}^{\mathrm{a}}$ & 0.07 & o & o \\
\hline Southern Lapwing Vanellus chilensis & & $\mathrm{O}^{\mathrm{a}}$ & o & o & 0.06 \\
\hline Campo Miner Geobates poecilopterus & & $\mathrm{O}^{\mathrm{a}}$ & o & 0.05 & o \\
\hline Rufous-collared Sparrow Zonotrichia capensis & & $\mathrm{O}^{\mathrm{a}}$ & o & 0.05 & o \\
\hline American Kestrel Falco sparverius & & $\mathrm{O}^{\mathrm{a}}$ & o & 0.03 & o \\
\hline Striped Owl Rhynoptinx clamator & & $\mathrm{O}^{\mathrm{a}}$ & o & 0.03 & o \\
\hline Brown-chested Martin Phaeoprogne tapera & & $\mathrm{O}^{\mathrm{a}}$ & o & 0.03 & o \\
\hline Grass Wren Cistothorus platensis & & $\mathrm{O}^{\mathrm{a}}$ & o & 0.03 & o \\
\hline
\end{tabular}

${ }^{a}=$ not significant, ${ }^{b}=p<0.05$ (Kruskal Wallis test) 


\section{References}

Ab' Saber, A. N. (1977) Os domínios morfoclimáticos da América do Sul. Primeira aproximação. Geomorfologia 52: 1-21.

Berardi, A. (1994) Effects of the african grass Melinis minutiflora on the plant community composition and the fire characteristics of a central brasilian savanna. MSc dissertation, University of London.

Bibby, C. J., Phillips, B. N. and Seddon, J. E. (1985) Birds of restocked conifer plantations in Wales. J. Appl. Ecol. 22: 619-633.

Bierregaard, R. O. and Stouffer, P. C. (1997) Understory birds and dynamic habitat mosaic in amazonian rainforests. Pp. ${ }^{138-155}$ in W. F. Laurance and Bierregaard, R. O., eds. Neotropical forest remnants. Ecology, management and conservation of fragmented communities. Chicago: University of Chicago Press.

Brower, J. E. and Zar, J. H. (1984) Field and laboratory methods for general ecology. Dubuque: McGraw-Hill.

Brown, A. F. and Stillman, R. A. (1993) Bird-habitat associations in the eastern highlands of Scotland. J. Appl. Ecol. 30: 31-42.

Castro, E. A. and Kauffman, J. B. (1998) Ecosystem structure in the Brazilian Cerrado: a vegetation gradient of aboveground biomass, root mass and consumption by fire. $J$. Trop. Ecol. 14: 263-283.

Cavalcanti, R. B. (1992) The importance of forest edges in the ecology of open country cerrado birds. Pp. 513-518 in P. A. Furley, J. Proctor and Ratter, J. A., eds. Nature and dynamics of forest-savanna boundaries. London: Chapman \& Hall.

Dias, B. F. S. (1993) Conservação da natureza no Cerrado brasileiro. Pp. 607-663 in M. N. Pinto (org.) Cerrado: caracterização, ocupação e perspectivas. Brasília: Editora Universidade de Brasília.

Douglas, M. E. and Endler, J. A. (1982) Quantitative matrix comparisons in ecological and evolutionary investigations. J. Theor. Biol. 99: 777-795.

Eiten, G. (1993) Vegetação do Cerrado. Pp 17-73 in M. N. Pinto (org.) Cerrado: caracterização, ocupação e perspectivas. Brasília: Editora Universidade de Brasília.

Ferreira, A. A. (1996) Dinâmica de comunidades de aves em fragmentos de Mata de Galeria. MSc dissertation, Universidade de Brasília.

Figueiredo, S. V. (1991) Efeito do fogo sobre o comportamento e sobre a estrutura da avifauna de cerrado. MSc dissertation, Universidade de Brasília.

Filgueiras, T. S. (1991) A floristic analysis of the gramineae of Brazil's Distrito Federal and a list of the species occurring in the area. Edinb. J. Bot. 48: 73-80.

Greenberg, C. H., Harris, L. D. and Neary, D. G. (1995) A comparison of bird communities in burned and salvage-logged, clearcut, and forested Florida sand pine scrub. Wilson Bull. 107: 40-54.

Johns, A. D. (1991) Responses of Amazonian rain forest birds to habitat modification. J. Trop. Ecol. 7: 417-437.

Karr, J. M. (1971) Structure of avian communities in selected Panama and Illinois habitats. Ecol. Monogr. 41: 207-232.

Kikkawa, J. (1982) Ecological associations of birds and vegetation structure in wet tropical forests of Australia. Aust. J. Ecol. 7: 325-345.

Klink, C. A. (1996) Germination and seedling establishment of two native and one invading African grass species in the Brazilian cerrado. J. Trop. Ecol. 12: 139-147.

Lamb, D., Parrotta, J., Keenan, R. and Tucker, N. (1997) Rejoining habitat remnants: restoring degraded rainforest lands. Pp. $366-385$ in W. F. Laurance and Bierregaard, R. O., (eds.) Neotropical forest remnants. Ecology, management and conservation of fragmented communities. Chicago: University of Chicago Press.

Lins, L. V. (1994) O papel da mata ciliar na estruturação de uma comunidade de aves do 
cerrado (Brasília, DF). MSc dissertation, Belo Horizonte, Universidade Federal de Minas Gerais.

MacNally, R. C. (1990) The roles of floristics and physiognomy in avian community composition. Austr. J. Ecol. 15: 321-327.

Mason, D. (1996) Responses of Venezuelan understory birds to selective logging, enrichment strips, and vine cutting. Biotropica 28: 296-309.

Myers, N., Mittermeier, R. A., Mittermeier, C. G., Fonseca, G. A. B. and Kent, J. (2000) Biodiversity hotspots for conservation priorities. Nature 403 (24): 853-858.

Negret, A. J. (1983) Diversidade e abundância da avifauna da reserva ecológica do IBGE, Brasília-DF. MSc dissertation, Universidade de Brasília.

Pinto, M. N. (ed.) (1993) Cerrado: caracterização, ocupação e perspectivas. Brasília, Ed. Univ. Brasília.

Pivello, V. R., Carvalho, V. M. C., Lopes, P. F., Peccinini, A. A. and Rosso, S. (1999a) Abundance and distribution of native and alien grasses in a "Cerrado" (Brazilian savanna) biological reserve. Biotropica 31: 71-82.

Pivello, V. R., Shida, C. N. and Meirelles, S. T. (1999b) Alien grasses in Brazilian savannas: a threat to the biodiversity. Biodivers. Conserv. 8: 1281-1294.

Reynolds, R. T., Scott, J. M. and Nusbaum, R. A. (1980) A variable circular plot method for estimating bird numbers. Condor 82: 309-313.

Ribeiro, J. F., Sano, S. M., Macedo, J. and Silva, J. A. (1983) Os principais tipos fisionômicos da região dos cerrados. Bol. de Pesquisa (Embrapa-CPAC) 21: 1-28.

Rotenberry, J. T. (1985) The role of habitat in avian community composition: physiognomy or floristics? Oecologia 67: 231-217.

Rotenberry, J. T. and Wiens, J. A. (1980) Habitat structure, patchiness, and avian communities in North American steppe vegetation: a multivariate analysis. Ecology 61: 12281250.

Sarmiento, G. (1983) The savannas of tropical America. Pp. 245-288 in F. Bourliére, ed. Ecosystems of the world, 13. Tropical savannas. Amsterdam: Elsevier.

Silva, J. M. C. (1995) Birds of the Cerrado region, South America. Steenstrupia 21: 69-92.

Stotz, D. F., Fitzpatrick, J. W., Parker III, T. A. and Moskovits, D. K. (1996) Neotropical birds: ecology and conservation. Chicago: University of Chicago Press.

Wiens, J. A. and Rotenberry, J. T. (1985) Response of breeding passerine birds to rangeland alteration in a North American shrubsteppe locality. J. Appl. Ecol. 22: 655-668.

Willis, E. O. and Oniki, Y. (1992) The losses of São Paulo birds are worse in the interior than in Atlantic forests. Ciênc. Cult. 44: 326-328.

Woinarski, J. C. Z. (1990) Effects of fire on the bird communities of tropical woodlands and open forests in northern Australia. Austr. J. Ecol. 15: 1-22.

Woinarski, J. C. Z. (1993) A cut-and-paste community: birds of Monsoon rainforests in Kakadu National Park, Northern Territory. Emu 93: 100-120.

DÁRIUS P. TUBELIS

Universidade de Brasília, Departamento de Ecologia, Brasília, DF, 70910-900, Brasil.

Current address: Departamento de Zoologia, Universidade de Brasília, Brasília, DF, 70910-90o, Brasil.E-mail: dtubelis@yahoo.com

ROBERTO B. CAVALCANTI

Universidade de Brasília, Departamento de Zoologia, Brasília, DF, 70910-900, Brasil. E-mail: rbc@tba.com.br 